Federal Reserve Bank of Minneapolis

Quarterly Review

Fall 1980

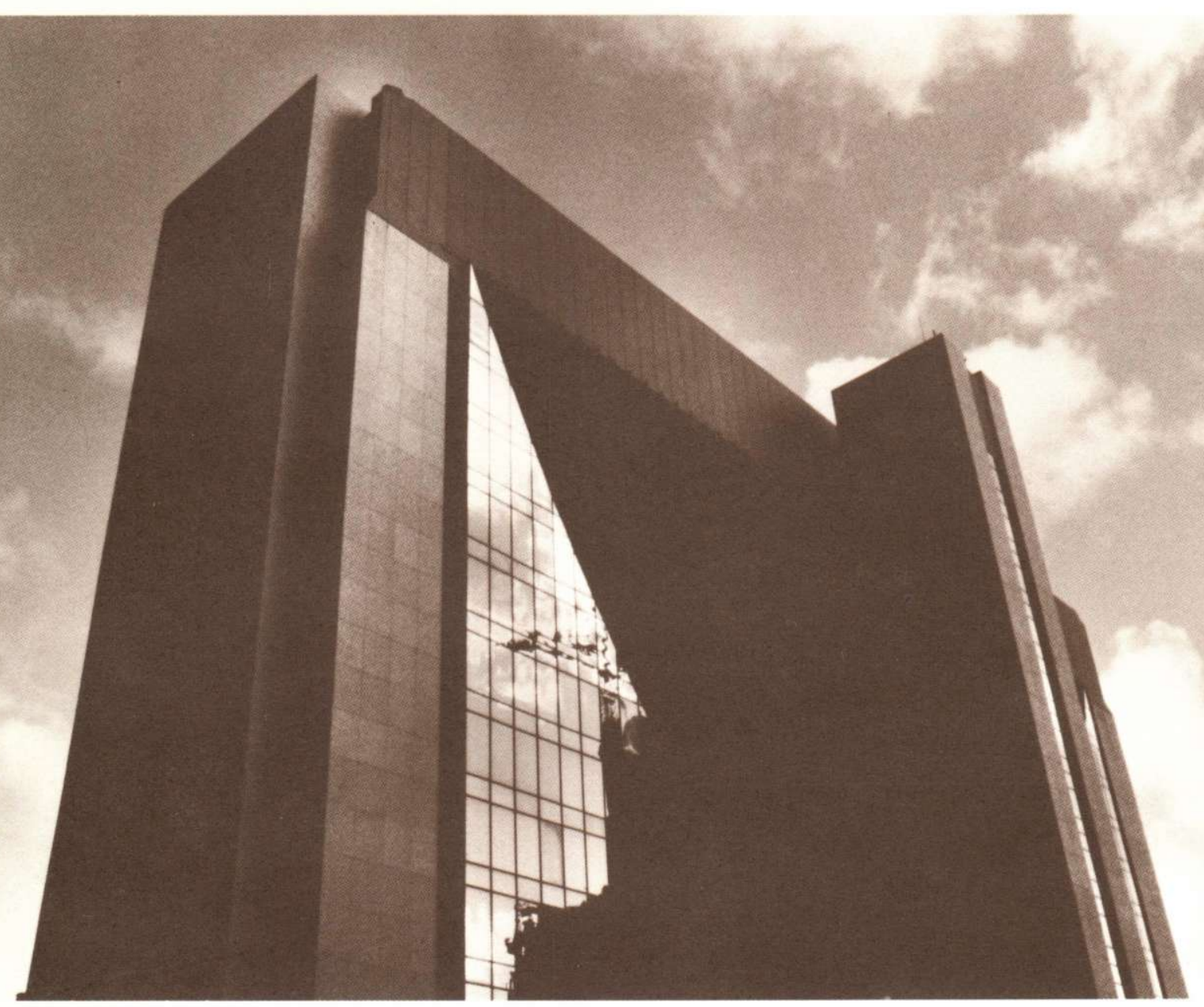

A New Approach to Monetary Control (p. 1)

Supply-Side Tax Cuts:

Will They Reduce Inflation? (p. 6)

Integrating Micro and Macroeconomics: An Application to Credit Controls (p. 16)

District Conditions (p. 30) 
Federal Reserve Bank of Minneapolis Quarterly Review vol. 4, No. 4

This publication primarily presents economic research aimed at improving policymaking by the Federal Reserve System and other governmental authorities.

Produced in the Research Department. Edited by Arthur J. Rolnick, Kathleen S. Rolfe, and Alan Struthers, Jr. Graphic design and charts drawn by Phil Swenson, Graphic Services Department.

Address requests for additional copies to the Research Department,

Federal Reserve Bank, Minneapolis, Minnesota 55480.

Articles may be reprinted if the source is credited and the Research

Department is provided with copies of reprints.

The views expressed herein are those of the authors and not necessarily those of the Federal Reserve Bank of Minneapolis or the Federal Reserve System. 


\section{District Conditions}

In 1980, the Ninth District had inflation about as high as in 1979 and its economy grew less than in 1979 , roughly as we predicted.* Our growth forecast, however, was too high. For 1981, our best guess is that the district will still have double-digit inflation and that its economy will grow faster than it did last year.

\section{0: High Inflation, Very Little Growth}

A year ago, our regional forecasting model indicated that between 1979 and 1980 the Minneapolis-St. Paul consumer price index (CPI) would rise 13 percent and Ninth District employment, our best available measure of overall economic activity, would rise 2 percent.

Our forecast was only partly correct. Our inflation forecast was realized. Our current estimate, using quarterly data through September, is that the Minneapolis-St. Paul CPI rose 11 percent in 1980 - about what we forecast. The district's inflation in 1980 was, for comparison, about the same as in 1979 but considerably higher than the 7 percent trend for the last decade. Our employment projection, unlike our inflation projection, was not realized. Our current estimate of the district's employment growth in 1980 is 0.8 percent, about half of what we forecast. The district's employment growth in 1980 was, for comparison, well below its trend growth of about 3 percent, a growth rate it was able to attain in 1979 . Its growth, however, was above the 0.3 percent estimated for the nation, and any employment increase looks good compared to the severe slowdowns in states to the east, where falling automobile sales resulted in sizeable employment declines.

Our employment forecast was high chiefly because we were too optimistic about agricultural conditions and the national economy. Agricultural conditions

*The Ninth Federal Reserve District consists of Minnesota, Montana, North and South Dakota, northwestern Wisconsin, and the Upper Peninsula of Michigan. deteriorated unexpectedly in the second quarter, when farm prices fell sharply and a spring and summer drought reduced crop yields and damaged grazing fields. Higher farm prices and midsummer rains came in the third quarter, too late for some farmers. Lower farm prices and output led to lower-than-expected employment in agriculture and in industries that supply farm inputs and sell farm commodities.

Also responsible for the district's unexpectedly low employment was a weaker-than-expected national economy. An already weakening national economy was pushed into a record-breaking, second-quarter plunge by high interest rates and credit controls. The high interest rates discouraged business and consumer spending. Credit controls also discouraged spending by making some borrowing more difficult, if not impossible. After interest rates fell and credit controls were terminated, the national economy began to recover in the third quarter, but the recovery was not brisk enough to offset the large second-quarter decline.

Some parts of the district were affected most by the poor agricultural conditions, others most by the weak national economy. The district consists of four geographic areas with distinct economic characteristics, as the accompanying map shows. Agriculture and energy mining dominate the two areas that comprise the district's center, and industrial activity dominates the district's eastern and western ends. In 1980, the drought and falling agricultural prices hurt the district's center the most. In this part of the district, however, the poor agricultural conditions were countered somewhat by expanding energy production and exploration in western North Dakota and eastern Montana. In the district's ends, where industrial activity is most important, the nationwide recession had its greatest effects. Here, lumbering, manufacturing, and metal mining were curtailed. 


\section{Economic Areas in the Ninth Federal Reserve District \\ Major Industries: Agriculture; Mining and Manufacturing}

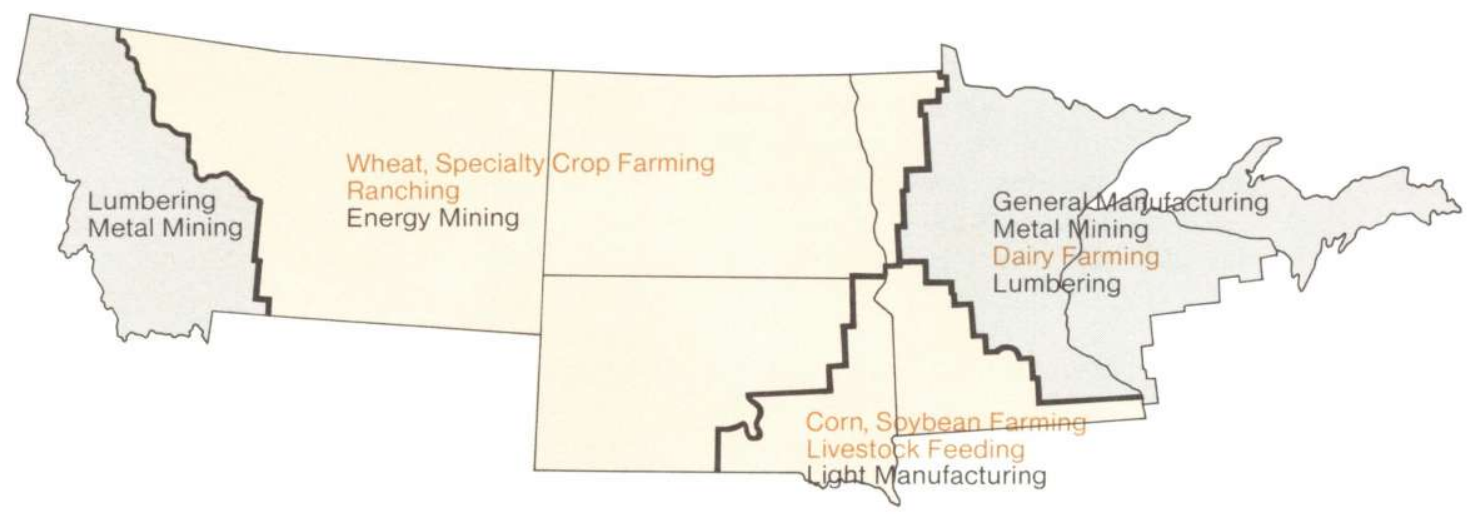

Source: Bogue, Donald J., and Beale, Calvin L. Economic Areas of the United States. Free Press of Glencoe, Inc., 1961

\section{1: More High Inflation, A Pickup in Growth} In 1981, we expect inflation again to be high in the district. Our regional forecasting model predicts that the Minneapolis-St. Paul CPI will increase 10 percent, down only 1 percentage point from 1980 . This projection of inflation is plausible in light of recent price increases and other 1981 forecasts.

In 1981, we expect employment in the district to increase at a rate faster than last year's, but slower than the 3 percent trend rate for the last decade. We think that employment will increase roughly 1.5 percent over the year. This projection is based on two assumptions: that the nation's economy will grow about as fast as it did last year, and that the region's economic growth will be considerably larger than the nation's, thanks to improved agricultural conditions.

Our employment forecast is more subjective this year because we could not completely rely on our forecasting model. The model projects that Ninth District employment will increase 3 percent in 1981. We thought this was too optimistic because of the current level of interest rates. Although the model's past employment projections have been reasonably accurate, its projections are based entirely on historical trends.
The model thus tells us what would happen to employment if 1981 were a typical recovery year. But 1981 is atypical in a very important way: interest rates at the beginning of the year were at historical highs, far higher than they usually are at the start of a typical recovery. These high rates will increase business caution about inventory and investment spending, which will hold down industrial output. They will also continue to hold down home sales. With high interest rates restraining business activity, retail sales gains will also be modest. All this will likely mean less employment than in a typical recovery year.

In 1981, unlike 1980, the predominately agricultural areas of the district will fare better than the predominately industrial areas. In the district's center, the expected improvement in agricultural conditions is large enough to virtually assure that the district's overall employment will grow more in 1981 than in 1980 . Because last year's poor weather reduced worldwide agricultural production, high farm prices are expected in 1981; the U.S. Department of Agriculture currently estimates that net farm income for the nation will rise from $\$ 23$ billion in 1980 to $\$ 31$ billion in 1981 . Prospects are particularly bright for growers of corn and 
soybeans, for their prices are foreseen jumping 42 and 38 percent, respectively, during the current market year.

At the eastern and western ends of the district, 1981's employment gains are not likely to be above 1980 's, because lumbering and building-supply manufacturing will be held down by weak housing activity. Other manufacturers' production will be dampened by weaknesses in consumer and business spending, and only a small rebound in metal mining is likely because of difficulties in the auto industry. 